\title{
Comparison of Cervical Cytological Screening Results Between Postmenopausal and Elderly Women
}

\section{Geriatrik ve Postmenopozal Kadınların Servikal Sitoloji Sonuçlarının Karşılaştırılması}

\author{
Bülent ÇAKMAK', Doğan Reşid KÖSEOĞLU² \\ Departments of ${ }^{1}$ Obstetrics and Gynecology and ${ }^{2}$ Pathology, Gaziosmanpaşa University, Faculty of Medicine, TOKAT, TURKEY
}

\begin{abstract}
Objective: There is insufficient data on geriatric period cervical cytology screening in our country. The aim of this study was to compare the cervical cytological results among elderly women and women aged between 45-64 years.
\end{abstract}

Material and Method: A comparison of cervical cytological results of 273 women aged over 65 years and 388 women aged between 45-64 years from January 2010 to June 2013 was performed for presence of cytological abnormalities. Adequacy was assessed according to the criteria of the 2001 Bethesda System. Cervical cytological abnormalities were classified as follows: atypical squamous cell of undetermined significance (ASCUS), cannot exclude a high-grade squamous intraepithelial lesion (ASC-H), low grade squamous intraepithelial lesion (LSIL), high grade squamous intraepithelial lesion (HSIL) and squamous cell carcinoma (SSC).

Results: Overall, the prevalence of cytological abnormality was 3\% and the prevalence of ASCUS, ASCH, LSIL, and HSIL was $1.8 \%$, $0.3 \%, 0.6 \%$ and $0.3 \%$, respectively. Cytological abnormalities were detected to be higher in the geriatric group in comparison to the postmenopausal group (\%5.1 vs. \%1.5) ( $\mathrm{p}=0.008)$. ASCUS was detected to be $3.7 \%$ in the geriatric group and $0.5 \%$ in the postmenopausal group $(\mathrm{p}=0.005)$. There was no statistically significant difference between the groups in means of other cytological anomalies. The reactive inflammatory changes were detected more in the postmenopausal group and atrophic changes in the geriatric group $(\mathrm{p}<0.001)$.

Conclusion: It should not be forgotten that although the cervical screening follow-up program is discontinued in elderly women, squamous intraepithelial lesions can still be encountered in this group even if the rate is low.

Key Words: Cervical smear, Cervical intraepithelial neoplasms, Aged, Turkey

\section{INTRODUCTION}

Worldwide, cervical cancer is still the most common type for women, especially in sub-Saharan Africa (1). Globally, $15 \%$ of all cancers in women are cervical cancer. Cervical

(Turk Patoloji Derg 2014, 30:38-42)

Received : 05.08.2013 Accepted : 02.12.2013
ÖZ

Amaç: Ülkemizde geriatrik dönem servikal sitoloji taraması ile ilgili veriler yetersizdir. Bu çalışmanın amacı, geriatrik ( $>65$ yaş) ve postmenopozal (45-64 yaş) kadınların servikal sitoloji sonuçlarının karşılaştırılmasıdır.

Gereç ve Yöntem: Ocak 2010 - Haziran 2013 tarihleri arasında servikal sitoloji taraması yapılan 273 geriatrik ve 388 postmenopozal kadının servikal sitoloji sonuçları sitolojik anormallik varlı̆̆ı açısından karşılaştırıldı. Değerlendirmede Bethesda Sistemi (2001) kullanıldı. Sitolojik anormallikler "atypical squamous cell of undetermined significance" (ASCUS), "cannot exclude a high-grade squamous intraepithelial lesion" (ASC-H), "low grade squamous intraepithelial lesion" (LSIL), "high grade squamous intraepithelial lesion" (HSIL), "squamous cell carcinoma" (SSC) şeklinde sinıflandırıldı.

Bulgular: Genel olarak sitolojik anormallik \%3 oranında ve ASCUS, ASCH, LSIL ve HSIL sirasiyla $\% 1,8, \% 0,3, \% 0,6$ ve $\% 0,3$ oranında tespit edildi. Sitolojik anormallik geriatrik grupta postmenopozal gruba göre daha yüksek oranda tespit edildi $(\% 5,1$ vs $\% 1,5)(\mathrm{p}=0.008)$. Sitolojik anormallikler içerisinde ASCUS geriatrik grupta \%3,7 ve postmenopozal grupta $\% 0,5$ oranında saptand $1(\mathrm{p}=0,005)$. Diğer sitolojik anormallikler açısından iki grup arasında istatistiksel fark saptanmadı. Reaktif inflamatuar değişiklikler postmenopozal grupta daha fazla saptanırken atrofik değişiklikler geriatrik grupta daha yüksek oranda saptandı $(\mathrm{p}<0,001)$.

Sonuç: Servikal sitolojik tarama programı geriatrik grupta devam etmediğinden bu grup kadınlarda düşük oranda da olsa SIL rastlanabildiği unutulmamalıdır

Anahtar Sözcükler: Servikal yayma, Servikal intarepitelyal neoplazi, Yaşl, Türkiye

cancer is a major cause of death in women living in developing countries (2). According to the GLOBOCAN data base, cervical cancer is the eighth most common cancer among women and twelfth among cancer-related deaths in

Correspondence: Bülent ÇAKMAK

Gaziosmanpaşa Üniversitesi, Tip Fakültesi, Kadın Hastalıkları ve Doğum

Anabilim Dalı, TOKAT, TURKEY

E-mail: drbulentcakmak@hotmail.com Phone: +90 3562129500 
Turkey. Almost one third of the 1443 patients diagnosed with cervical cancer each year in Turkey die because of the disease (3).

Papanicolaou (Pap) smear is currently used as a cheap and simple method for cervical cancer and preinvasive cervical lesion screening. Cervical cancer screening with cytology has successfully decreased the incidence and mortality of cervical cancer. Cervical cancer was the primary cause of cancer deaths for American women fifty years ago. The introduction of the Pap smear for cancer screening in 1945 and cervical cancer screening programs in the United States have reduced cervical cancer mortality by $70 \%(4,5)$. This reduction in mortality is due to an increase in the detection of invasive cancer at early stages and the detection and treatment of preinvasive lesions (6).

Despite the significant improvement in cervical cancer death rates, there are still conflicted opinions about appropriate cancer screening protocols throughout the life span (5). Regular Pap smear screening is usually recommended until the age of 65-70. Thus the rate of cervical cancer has successfully decreased. If there is no previous screening, screening may be useful after the age of 65-70 (7). In this article we aimed to compare the Pap smear results between postmenopausal women of 45-64 ages and over 65 .

\section{MATERIAL and METHODS}

This retrospective study was carried out at the Obstetrics and Gynecology Clinic of Gaziosmanpaşa University Hospital. The study protocol was approved by the Local Ethics Committee of Gaziosmanpaşa University, Faculty of Medicine. Cervical cytology materials obtained from the patients that presented to the Gynecology and Obstetrics outpatient department between January 2010 and June 2013 for screening or any complaint. The data of 273 postmenopausal geriatric ( $>65$ years old) women and 388 postmenopausal non-geriatric women (45-64 years old) with cervical Pap smear results were evaluated. Demographic data and cervical cytological results of geriatric and non-geriatric women were compared.

Data of the demographic characteristics included age, gravidity, parity, time of menopause, use of hormone replacement therapy (HRT) and smoking. Women with premature menopause (menopause $<40$ years old), using HRT and with a history of cervical intraepithelial neoplasia (CIN), cervical cancer or another genital malignancy were excluded from the study.

Cervical screening was performed by conventional Pap smear using the cytobrush. An adequate smear was defined as adequate squamous cells and presence of transformation sampling. Adequacy was assessed according to the criteria of the 2001 Bethesda System. Cervical smears were evaluated by two pathologists. However, in patients with a discordant diagnosis, results were reported by providing consensus after re-evaluation of slides by both pathologists. Cervical cytological data were classified as follows: negative for intraepithelial lesion or malignancy (NILM), reactive inflammatory changes, atrophic changes and cytological abnormality included atypical squamous cell of undetermined significance (ASCUS), cannot exclude a high-grade squamous intraepithelial lesion (ASC-H), low grade squamous intraepithelial lesion (LSIL), high grade squamous intraepithelial lesion (HSIL), squamous cell carcinoma (SSC).

All data were analyzed using "PASW Statistics version 18.0" (PASW, Chicago, IL, USA). Differences between the two groups of women were assessed using Chi-squared test, Fisher's Exact test and Mann-Whitney U-test for categorized variables, and Student's t-test for continuous variables. $\mathrm{P}<0.05$ was considered significant.

\section{RESULTS}

The research group of this study consisted of 661 postmenopausal women, 273 of which were geriatric and 388 were non-geriatric. Comparison of demographic characteristics of groups is given in Table I. Age and number of gravidity and parity were higher in the geriatric group compared to the non-geriatric group $(\mathrm{p}<0.001)$. Similarly, time of menopause was higher in geriatric group. In contrast, prevalence of HRT usage and previous Pap smear were higher in non-geriatric group. Prevalence of smoking was similar in both of the groups ( $p>0.05)$.

Overall, the prevalence of cytological abnormality was 3\%, and the prevalence of ASCUS, ASCH, LSIL, and HSIL was $1.8 \%, 0.3 \%, 0.6 \%$ and $0.3 \%$, respectively. The prevalence of negative for intraepithelial lesion or malignancy (NILM) was $97 \%$ (reactive inflammatory changes and atrophic changes were $64.6 \%, 32.4 \%$, respectively).

5 out of 12 patients who had a smear result of ASCUS were treated with local antibiotics and local estrogen. The post treatment results came back as NILM and were routinely monitored. Colposcopic biopsy was performed on 7 patients; 6 were detected to be chronic cervicitis and 1 came back as CIN-I. The 2 biopsy results of the patients who had ASCH came back as chronic cervicitis and CIN-I. Out of the 4 cases in which LSIL was detected biopsies were performed on 3 (one patient did not show up for follow up) and the results revealed CIN-I in two patients and chronic 
cervicitis in one patient. The colposcopic biopsy results of the two patients in which HSIL was detected came back as CIN-III.

The prevalence of NILM in the non-geriatric group was higher than the geriatric group $(98.5 \%$ vs. $94.9 \%)$. The prevalence of atrophic changes in the non-geriatric group was lower than the geriatric group ( $18.3 \%$ vs. $52.4 \%)$ $(\mathrm{p}<0.001)$. In contrast, reactive inflammatory detection rate was higher in the nongeriatric group $(\mathrm{p}<0.001)$. The prevalence of cytological abnormality was higher in the geriatric group $(5.1 \%$ vs. $1.5 \%)(\mathrm{p}=0.008)$. ASCUS was detected to be $3.7 \%$ in the geriatric group and $0.5 \%$ in the postmenopausal group ( $\mathrm{p}=0.005)$. There was no statistically significant difference between the groups in means of other cytologic anomalies. In addition, there was no cervical squamous or adenocarcinoma in each groups (Table II).

\section{DISCUSSION}

Postmenopausal hormonal changes such as hypoestrogenism may increase the likelihood of atrophic changes and cause inadequate findings on cervical cytology with atrophic changes of the genital tract. In addition, these changes may cause inadequate visualization of squamocolumnar junction in colposcopic examination (8). In the present study, the prevalence of atrophic changes on cervical cytology was determined higher in the geriatric group than the non-geriatric group (52.4\% vs. $18.3 \%)$. The proportion of atrophic changes on smear results is known to increase with age (9). On the other hand, postmenopausal women using exogenous estrogen in the form of hormone therapy (HT) have fewer atrophic changes than women who are not using estrogen therapy (10). In this study, prevalence of HRT usage was higher in the non-geriatric group, and the duration of postmenopausal period was found to be higher in the geriatric group $(p=0.02)$. Moreover, the high prevalence of atrophic changes in pap smear results in the geriatric group are due to the long duration of the postmenopausal period in the geriatric group and lower rate of HRT usage in the geriatric group compared to nongeriatrics. It should be noted, studies have shown that HRT is associated with cervical smear mimicking LSIL caused by cellular glycogenization (11), and current HRT usage

Table I: Comparison of demographic characteristics of groups

\begin{tabular}{|l|c|c|c|}
\hline Features & Non-geriatric group & Geriatric group & p value \\
\hline Age (years) & $56.6 \pm 5.0$ & $71.2 \pm 5.7$ & $<0.001$ \\
\hline Gravidity & $4[0-11]$ & $5[0-13]$ & $<0.001$ \\
\hline Parity & $4[0-10]$ & $5[0-12]$ & $<0.001$ \\
\hline Time of postmenopausal (years) & $8.0 \pm 6.0$ & $23.1 \pm 8.1$ & $<0.001$ \\
\hline HRT $^{\star}$ & $58 / 388(14.9 \%)$ & $25 / 273(9.2 \%)$ & 0.027 \\
\hline Previous Pap smear & $90 / 388(23.2 \%)$ & $14 / 273(5.1 \%)$ & $<0.001$ \\
\hline Smoking & $17 / 388(4.4 \%)$ & $16 / 273(5.9 \%)$ & 0.469 \\
\hline
\end{tabular}

${ }^{*}$ Hormone replacement therapy within the last three years.

Table II: Comparison of Pap smear results of groups

\begin{tabular}{|l|c|c|c|}
\hline Smear result & $\begin{array}{c}\text { Non-geriatric group } \\
\mathbf{n}(\%)\end{array}$ & $\begin{array}{c}\text { Geriatric group } \\
\mathbf{n}(\%)\end{array}$ & p value \\
\hline NILM $^{*}$ & $382(98.5)$ & $259(94.9)$ & 0.008 \\
\hline Reactive inflammatory changes & $311(80.2)$ & $116(42.5)$ & $<0.001$ \\
\hline Atrophic changes & $71(18.3)$ & $143(52.4)$ & $<0.001$ \\
\hline Cytological abnormality & $6(1.5)$ & $14(5.1)$ & 0.008 \\
\hline ASCUS & $2(0.5)$ & $10(3.7)$ & 0.005 \\
\hline ASC-H & $2(0.5)$ & $0(0)$ & 0.235 \\
\hline LSIL & $1(0.3)$ & $3(1.1)$ & 0.170 \\
\hline HSIL & $1(0.3)$ & $1(0.4)$ & 0.802 \\
\hline
\end{tabular}

*Negative for intraepithelial lesion or malignancy. 
may affect the change in squamous cervical cytological abnormalities, such as ASCUS (12).

Cervical preinvasive lesions have a crucial role for development of cervical cancer. Cervical cancer has a long preinvasive phase, and cervical screening and relevant management of these lesions can reduce the rate of cervical cancer with population based screening. The prevalence of cervical cytological abnormalities varies between $1.5 \%$ and $6 \%$ in developing countries (13). In addition, the prevalence of cervical cytological abnormalities in Turkey varies between $1.8 \%$ and $2.8 \%(14,15)$. Studies conducted by Cancer Early Diagnosis, Screening and Education Center (KETEM) revealed the prevalence of cervical cytological abnormalities to be approximately $1 \%(16,17)$. Kurdoğlu et al. (16) detected this value to be $1.19 \%$ in Van and Durak et al. (17) detected this value to be $1.03 \%$ in Antalya. In the present study, the prevalence of cytological abnormality was found higher (3\%) than these studies' results. The studies from Turkey include Turkish women of all ages, but our study includes only postmenopausal and elderly women. Also, the higher prevalence of cytological abnormality in our study may be due to this age difference.

According to the American Cancer Society (ACS), women at 70 years of age or older might choose to discontinue the Pap smear screening if they have had three or more normal Pap smear results in a row and had no abnormal Pap smear results in the last 10 years (18). The 2009 ACOG guidelines recommend stopping screening at the age of $65-70$ in patients with three consecutive normal Pap smears and no abnormal tests in the last 10 years (19). An update to the ACS guideline recommends that women aged older than 65 years with evidence of adequate negative prior screening and no history of CIN2+ within the last 20 years should not be screened for cervical cancer with any modality (20). There is no guideline associated with cervical cancer screening for Turkish women in Turkey. Generally, ACS guidelines are used for screening cervical cancer. In addition, random screening is fairly widespread in Turkey.

In our study using a regional screening program, the prevalence of cytological abnormality in geriatric group was higher than non-geriatric group (5.1\% vs. $1.5 \%)(\mathrm{p}=0.008)$. The rates of ASCUS, ASCH, LSIL and HSIL were similar in the both groups. In a study, the prevalence of cytological abnormality in a group of women aged over 65 was detected as $1.4 \%$ in France (21). According to this study, precancerous lesions and cervical cancer can be discovered after age 65 despite an adequate former follow-up. In our study, the prevalence of cytological abnormality was higher than this study. The probable cause of higher prevalence of cytological abnormality in the group of women over 65 years age in our study is lower follow-up rates for cervical screening. Similarly, in the non-geriatric group, as well as the geriatric group, rates of cervical screening followup was found lower (23.2\% and 5.1\%). Most studies have shown that women with abnormal Pap smears or no Pap smears in the past are at higher risk of developing cervical cancer than women who have been screened regularly (22).

In conclusion, the prevalence of cervical cytological abnormality was $3 \%$ in our study. In elderly (over aged 65 ) women as well as women aged between 45-64 years, cervical cytological abnormalities can be showed. It should be kept in mind; since the cervical screening follow up program is discontinued in elderly women, in this group squamous intraepithelial lesions can still be encountered even if the rate is low.

\section{REFERENCES}

1. Veldhuijzen NJ, Snijders PJ, Reiss P, Meijer CJ, van de Wijgert $\mathrm{JH}$. Factors affecting transmission of mucosal human papilloma virus. Lancet Infect Dis. 2010;10:862-74.

2. Jemal A, Bray F, Center MM, Ferlay J, Ward E, Forman D. Global cancer statistics. CA Cancer J Clin. 2011;61:69-90.

3. International Agency for Research on Cancer. Aviable at: http:// globocan.iarc.fr/factsheet.asp\#WOMEN

4. Spitzer M. Screening and management of women and girls with human papillomavirus infection. Gynecol Oncol. 2007;107:14-8.

5. Datta SD, Koutsky LA, Ratelle S, Unger ER, Shlay J, McClain T, Weaver B, Kerndt P, Zenilman J, Hagensee M, Suhr CJ, Weinstock H. Human papillomavirus infection and cervical cytology in women screened for cervical cancer in the United States, 20032005. Ann Intern Med. 2008;148:493-500.

6. Siegel R, Naishadham D, Jemal A. Cancer statistics, 2012. CA Cancer J Clin. 2012;62:10-29.

7. Rakel RE. The periodic health examination. In: Grimin KJ Diebold MM, editors. Textbook of family Practice. 6th edition. USA: WB Saunders Company; 2002. 159-182.

8. Dresang LT. Colposcopy: An evidence-based update. J Am Board Fam Pract. 2005;18:383-92.

9. Waddell CA. The influence of the cervix on smear quality. I: Atrophy. An audit of cervical smears taken post-colposcopic management of intraepithelial neoplasia. Cytopathology. 1997;8:274-81.

10. Gupta S, Kumar N, Singhal N, Manektala U, Jain S, Sodhani P. Cytohormonal and morphological alterations in cervicovaginal smears of postmenopausal women on hormone replacement therapy. Diagn Cytopathol. 2006;34:676-81.

11. Jemal A, Tiwari RC, Murray T, Ghafoor A, Samuels A, Ward E Feuer EJ, Thun MJ; American Cancer Society. Cancer statistics, 2004. CA Cancer J Clin. 2004;54:8-29.

12. Ahn KH, Kim T, Kim YT, Lee KW, Kim SH. Current hormone therapy associated with atypical squamous cells of undetermined significance in postmenopausal women. Int J Gynecol Cancer. 2009;19:699-702. 
13. Sigurdsson K, Sigvaldason H. Longitudinal trends in cervical cytological lesions and the effect of risk factors. A 30-year overview. Acta Obstet Gynecol Scand. 2006;85:350-8.

14. Turkish Cervical Cancer and Cervical Cytology Research Group. Prevalence of cervical cytological abnormalities in Turkey. Int J Gyneacol Obstet. 2009;106:206-9.

15. Atilgan R, Celik A, Boztosun A, Ilter E, Yalta T, Ozercan R. Evaluation of cervical cytological abnormalities in Turkish population. Indian J Pathol Microbiol. 2012;55:52-5.

16. Kurdoğlu Z, Kurdoğlu M, Kundakçı Gelir G, Keremoğlu Ö. Van Kanser Erken Teşhis, Tarama ve Eğitim Merkezi’ne ait serviks ve meme kanserlerini tarama programı sonuçları. Van Tıp Dergisi. 2009;16:119-23.

17. Durak S. Kanser kontrolünde birinci basamak sağlık kuruluşlarının rolünün Antalya Kanser Erken Teşhis ve Tarama Merkezi (KETEM) verileri ile değerlendirilmesi [Internet] Ankara 2006. Available from: http://www.phd.org.tr/sbil5.ppt

18. Smith RA, Cokkinides V, Brooks D, Saslow D, Shah M, Brawley OW. Cancer screening in the United States, 2011: A review of current American Cancer Society guidelines and issues in cancer screening. CA Cancer J Clin. 2011;61:8-30.
19. ACOG Committee on Practice Bulletins-Gynecology. ACOG Practice Bulletin no. 109: Cervical cytology screening. Obstet Gynecol. 2009;114:1409-20.

20. Saslow D, Solomon D, Lawson HW, Killackey M, Kulasingam SL, Cain J, Garcia FA, Moriarty AT, Waxman AG, Wilbur DC, Wentzensen N, Downs LS Jr, Spitzer M, Moscicki AB, Franco EL, Stoler MH, Schiffman M, Castle PE, Myers ER; ACS-ASCCPASCP Cervical Cancer Guideline Committee. American Cancer Society, American Society for Colposcopy and Cervical Pathology, and American Society for Clinical Pathology screening guidelines for the prevention and early detection of cervical cancer. CA Cancer J Clin. 2012;62:147-72.

21. Meyer R, Lemay AL, Guy X, Giraud C, Mathevet P, Flori M. Is there a benefit to continue pap smear screening for cervical cancer after 65 years of age? A retrospective study on 53,644 women. Bull Cancer. 2012;99:409-15.

22. Schwaiger C, Aruda M, LaCoursiere S, Rubin R. Current guidelines for cervical cancer screening. J Am Acad Nurse Pract. 2012;24:417-24. 